\title{
Fatal case of Clostridium perfringens enteritis and bacteraemia in South Africa
}

\author{
Anthony M. Smith ${ }^{1,3}$, Juno Thomas ${ }^{2,3}$, Pieter J. H. Mostert ${ }^{4}$ \\ ${ }^{1}$ Enteric Diseases Reference Unit, National Institute for Communicable Diseases, Johannesburg, South \\ Africa \\ ${ }^{2}$ Outbreak Response Unit, National Institute for Communicable Diseases, Johannesburg, South Africa \\ ${ }^{3}$ University of the Witwatersrand, Johannesburg, South Africa \\ ${ }^{4}$ Tzaneen Medi-Clinic, Tzaneen, South Africa
}

\begin{abstract}
Clostridium perfringens is an important anaerobic pathogen causing foodborne and non-foodborne gastrointestinal diseases in humans and animals. This pathogen is also the more common Clostridium species associated with bacteraemia. We report on a fatal case of $C$. perfringens infection in an adult with type 2 diabetes.
\end{abstract}

Key words: Clostridium perfringens, necrotising enteritis, bacteraemia, South Africa

J Infect Dev Ctries 2011; 5(5):400-402.

(Received 22 September 2010 - Accepted 15 February 2011)

Copyright (C) 2011 Smith et al. This is an open-access article distributed under the Creative Commons Attribution License, which permits unrestricted use, distribution, and reproduction in any medium, provided the original work is properly cited.

\section{Introduction}

Clostridium perfringens is an important anaerobic pathogen causing foodborne and nonfoodborne gastrointestinal diseases in humans and animals. Clostridial species are also a common cause of anaerobic bacteraemia, with $C$. perfringens the most commonly isolated species $[1,2]$. Clostridial bacteraemia is associated with high mortality rates (approaching 50\%) despite appropriate medical/surgical management and antimicrobial therapy [3]. Enteritis necroticans, also called pigbel, is an often fatal type of gastrointestinal infection typically caused by $C$. perfringens type $\mathrm{C}$, although case reports and series have described $C$. perfringens type A causing this disease as well [4]. Risk factors for developing enteritis necroticans include diabetes mellitus, protein malnutrition, the sudden intake of protein-rich meals, and high amounts of dietary trypsin inhibitors. The disease is characterised by segmental haemorrhagic necrosis of the jejunum, which rapidly progresses to full-thickness necrosis of small and occasionally large bowel segments $[5,6]$. Clinical features include severe abdominal pain, vomiting, diarrhoea (often with blood), followed by constipation, intestinal obstruction and hypotension and may be rapidly progressive $[5,7]$.

\section{Case report}

On 14 October 2009, in the town of Tzaneen, South Africa, a 61-year-old male presented to hospital with a one-day history of fever with rigors, nausea and weakness followed by profuse watery diarrhoea. The patient deteriorated rapidly during the evening, and on admission to hospital the following morning was noted to be febrile and hypotensive, with a decreased level of consciousness and continuous green watery diarrhoea. Shortly afterwards he developed clinical evidence of disseminated intravascular coagulation and asystole, and died despite intensive resuscitation efforts. No autopsy was performed. He had a history of hypercholesterolaemia and uncontrolled type 2 diabetes; the diabetes had been diagnosed five years previously but he had stopped taking medication after two years as he believed he had been cured. It was reported that he had been experiencing excessive thirst for several months, but had not sought medical attention. Routine blood tests done prior to death, including blood cultures (aerobic and anaerobic culture), did not elucidate the aetiology of the illness. The presence of a bacteraemia was investigated as follows: a sample of the patient's blood was processed to extract genomic DNA using the MagNA Pure Compact Nucleic Acid Isolation Kit I (Roche Diagnostics GmbH, Mannheim, Germany). The 
DNA extraction was analyzed using PCR aimed at amplification of bacterial $16 \mathrm{~S}$ ribosomal RNA (rRNA) DNA. The sequence of PCR primers were as follows: AGAGTTTGATCYTGGYTYAG and ACGGCTACCTTGTTACGACTT. The PCR included 30 cycles of $95^{\circ} \mathrm{C}$ for 1 minute, $55^{\circ} \mathrm{C}$ for 2 minutes and $72^{\circ} \mathrm{C}$ for 2 minutes, and employed AmpliTaq Gold DNA polymerase enzyme (Applied Biosystems, Foster City, USA). The amplified 16S rRNA gene product $(\sim 1500$ base pairs) was purified from the PCR using the MSB Spin PCRapace Kit (Invitek, Berlin, Germany). The gene was sequenced using the BigDye Terminator v3.1 Cycle Sequencing Kit (Applied Biosystems) and an Applied Biosystems 3130 Genetic Analyzer. The nucleotide sequence of the gene was examined against the DNA database of the National Center for Biotechnology Information (NCBI) using the BLAST algorithm (http://www.ncbi.nlm.nih.gov/). PCR amplification of a bacterial 16S rRNA gene and DNA sequence analysis of the gene determined the presence of $C$. perfringens in the bloodstream of the patient. Our sequence analysis revealed a $100 \%$ match with $C$. perfringens genes listed in the NCBI database.

\section{Discussion}

In the present case study, we report on a fatal case of $C$. perfringens infection in an adult with type 2 diabetes. Clostridial bacteraemia was diagnosed genetically and involved PCR and DNA sequence analysis of the bacterial $16 \mathrm{~S}$ rRNA gene, which is a well-documented and well-established method [8-10]. Fulminant $C$. perfringens disease with enteritis necroticans in diabetic patients is well described, and perhaps attributable to diabetes-related gastrointestinal dysfunction allowing overgrowth of the organism and facilitating its pathogenesis [5]. $C$. perfringens is ubiquitous, found in soil and the gastrointestinal tracts of many animals including humans, in whom asymptomatic carriage is common in endemic regions. Outbreaks and sporadic cases of enteritis necroticans have been linked to inadequately cooked food-animal products. Affected persons usually have underlying risk factors, including the classic association with protein malnutrition and the more recently recognised association with diabetes. In this case, we hypothesise that the source of our patient's infection was most likely a contaminated food source. He belonged to a ministry that provided food to needy children by collecting and distributing donated foods (including meat) which were usually past their expiry dates. He assisted in handling and preparation of this food for distribution, and also ate this food occasionally. Fortunately, no other cases of gastrointestinal illness were identified in the community.

In conclusion, our genetic diagnosis of $C$. perfringens bacteraemia was supported by the patient's clinical presentation, which is in keeping with previously published case reports of enteritis necroticans in diabetic patients. Diabetes is emerging as one of the most prevalent noncommunicable diseases in South Africa [11], and healthcare workers should be cognisant of the range of unusual infectious diseases that may afflict diabetic patients.

\section{References}

1. Leal J, Gregson DB, Ross T, Church DL, Laupland KB (2008) Epidemiology of Clostridium species bacteremia in Calgary, Canada, 2000-2006. J Infect 57: 198-203.

2. Woo PC, Lau SK, Chan KM, Fung AM, Tang BS, Yuen KY (2005) Clostridium bacteraemia characterised by 16S ribosomal RNA gene sequencing. J Clin Pathol 58: 301-307.

3. Rechner PM, Agger WA, Mruz K, Cogbill TH (2001) Clinical features of clostridial bacteremia: a review from a rural area. Clin Infect Dis 33: 349-353.

4. Sobel J, Mixter CG, Kolhe P, Gupta A, Guarner J, Zaki S, Hoffman NA, Songer JG, Fremont-Smith M, Fischer M, Killgore G, Britz PH, MacDonald C (2005) Necrotizing enterocolitis associated with clostridium perfringens type A in previously healthy north american adults. J Am Coll Surg 201: 48-56.

5. Petrillo TM, Beck-Sague CM, Songer JG, Abramowsky C, Fortenberry JD, Meacham L, Dean AG, Lee H, Bueschel DM, Nesheim SR (2000) Enteritis Necroticans (Pigbel) in a Diabetic Child. N Engl J Med 342: 12501253.

6. Gui L, Subramony C, Fratkin J, Hughson MD (2002) Fatal enteritis necroticans (pigbel) in a diabetic adult. Mod Pathol 15: 66-70.

7. Murrell TG and Walker PD (1991) The pigbel story of Papua New Guinea. Trans R Soc Trop Med Hyg 85: 119-122.

8. Clarridge III JE (2004) Impact of 16S rRNA Gene Sequence Analysis for Identification of Bacteria on Clinical Microbiology and Infectious Diseases. Clin Microbiol Rev 17: 840-862.

9. Janda JM and Abbott SL (2007) 16S rRNA Gene Sequencing for Bacterial Identification in the Diagnostic Laboratory: Pluses, Perils, and Pitfalls. J Clin Microbiol 45: 2761-2764.

10. Smith AM, Perovic O, Sooka A, Venturas JP, Richards GA (2003) Enterococcus avium with atypical phenotypic characteristics. Southern Afr J Epidemiol Infect 18: 42-44.

11. Mayosi BM, Flisher AJ, Lalloo UG, Sitas F, Tollman SM, Bradshaw D (2009) The burden of noncommunicable diseases in South Africa. Lancet 374: 934-947. 


\section{Corresponding author}

Dr Anthony Smith

Enteric Diseases Reference Unit

National Institute for Communicable Diseases

Private Bag X4, Sandringham, 2131

Gauteng, South Africa

Telephone: +27-11-5550348

Fax: +27-11-5550433

Email: anthonys@nicd.ac.za

Conflict of interests: No conflicts of interest are declared. 